\title{
Economic Conservatism in Theory and Practice
}

\author{
Dr. Hakan Köni \\ Senior Lecturer, Faculty of Islamic Civilization, University Technology Malaysia \\ hakankoni@utm.my
}

\section{Doi:10.5901/mjss.2016.v7n3p11}

\begin{abstract}
This article investigates the major characteristics and principles of economic conservatism with an analysis of the ideas of medieval and later religious scholars in the Christian and the Muslim world, mercantilism as an economic currency of thought, and the advocacies and the campaigns of the conservative political movements and thinkers in the economic sphere to the early $20^{\text {th }}$ century. It is argued in the article that these actors and phenomena have contributed to the formation of a conservative view to economy which cast itself in form of support for extensive state involvement in the economy, development of national economies, public welfare, social state, taxation of the wealth, favourable trade balance, distributive justice, agrarianism; and opposition to monopolization, black-marketing, speculation, interest, usury, luxury, indulgence, acquisition of wealth without moral concern. Particularly in the US example from $19^{\text {th }}$ century onwards, reaction to capitalism was the most important second characteristic of economic conservatism after the support for an economically active state for capitalism was deemed to suffer from a substantial moral gap that threatened the social foundations of the country.
\end{abstract}

Keywords: Economic conservatism, Christian economic thought, Islamic economic thought, mercantilism, American conservatism.

\section{Introduction}

The view of the conservative political parties to economy is not very easily ascertained unlike those of the liberals or the social democrats. That is the case for conservative parties in the west but also for those in the Islamic world. The specialists are confounded about whether there is a conservative approach to economy rooted in its ideational and empirical roots. The traditional support of conservative political parties for substantial state activism in economy, social policy and welfare issues is sometimes claimed to be a pragmatist imitation of social democrats. And similarly, the endorsement of private property, production and trade is argued to be imported from liberalism. But most of these are not the case. Economic conservatism has a much longer history and it has its characteristics shaped much before the emergence of liberalism or socialism. The first and the most important contribution to the formation of economic conservatism comes from the views of the medieval religious scholars of Islamic and Christian world like Farabi, Gazali, Ibnu Khaldun, Albertus Magnus, Thomas Aquinas, Martin Luther and John Calvin. The teachings and interpretations of these scholars pertaining to economic life are adopted in various ways by the founders of conservative political movements in party programs, electoral campaigns and government programs. The views of religious scholars, no matter to which religion they belong to, display significant similarities to reflect a unique logic and mentality which could be summarized briefly here as: Support for private property, production and trade for economic prosperity and liveliness; avoidance of luxury, indulgence and excessive consumption; prohibition of interest, monopolization, black-marketing, speculation, profiteering and such activities; state involvement in economy for purposes of regulation, control and distribution; belief in the necessity of an economically powerful state to distribute justice, public goods, and welfare; and taxation of economic activities at decent levels to meet public expenditures

The monarchies (and also the empires) follow the second in the formation of economic conservatism with their practices generally called as mercantilism motivated to organize the economy according to the state interests. Mercantilism foresaw the necessity of an economically powerful state with multiple channels of intervention to the economic life. That was needed for domestic purposes as the scholars often argued, but also to expand the borders and acquire colonies. What the monarchies were supposed to do to promote state interests was to collect huge state treasures, to spend that for raising armies with effective weapons, and to mobilize the private and public economies for this purpose with a zero-sum view to international economy. To be richer and more powerful, the countries were supposed to promote domestic production and exports while the imports had to be restricted. Countries had to control and regulate the economy and make necessary investments in areas where the entrepreneurs failed. 
The power of the religious and monarchical institutions tended to decline after the French Revolution, but only to give birth to political conservatism as a political movement in emerging democratic political systems to compete with its liberal and afterwards socialist rivals. In this context, conservatism had found one of its earliest expressions as a political movement in the US within the party organization of the Federalists, the Whigs and afterwards the Republicans from the late $18^{\text {th }}$ century onwards. In its American setting, the major principles and goals of economic conservatism could be stated in brief as state intervention in the economy; massive public investment and development programs; favorable trade balance via the promotion of exports against imports; achievement of the economic unity of the country; expansive welfare and social policy programs; support for private property and responsible private entrepreneurialism; reaction against capitalism, plutocracy, and bourgeois domination of the economy; support for agrarian way of life; reduction of the income gap between the rich and the poor; and distribution of property from the capitalists to the rest of the people. The article does not forget the tradition of libertarianism in conservative thought which stands in stark contrast to many of these mentioned above for which a small section is allocated at the end.

The objective of this study is thus the exploration of the major principles and advocacies of economic conservatism to clarify and advance the view of the researchers on the topic. The topic is a matter of curiosity and obscurity even for those who specialize on the history of economic thought who sometimes try to explain economic conservatism as a hybrid economic ideology formed with borrowings from rival economic thoughts and practices, the view that the author criticizes here in an indirect way. The methodology that will be followed to achieve this objective will include, first, the analysis of the teachings and the doctrines of the medieval religious scholars like Magnus, Aquinas, Martin Luther, Calvin, ibnu Khaldun, Gazali as well as various original religious sources; second, the review of the views of the contemporary scholars of economic thought; and, third, the examination of the economic practices and advocacies of conservatives in the US with a look at the scholarly publications, party policies, political campaigns and government programs.

\section{Scholastic Scholars}

The scholastic scholars of the medieval ages like Albertus Magnus, Thomas Aquinas and Nichole Oresme shared significant similarities in their view to major norms and principles to be followed in economic life. On the common base of their view was laid the Aristotelian view that man was a social being; that man was in a constant state of needs; that human needs were not uniform but variegated; and that man had to live in cooperation with the others to meet his various needs. It followed from these contentions that man had to work to meet his needs; that he had to trade with the others for those materials and other staff that he could not produce himself; and that he had to observe some principles of concern for public life to facilitate these activities (Hagan, 2012: 3-14). This also required the man to specialize on certain economic activities to put forward unique products that the others needed but could not produce.

While production and trade were necessary according to the scholastic scholars, there had to be certain limits on the practice of production and trade. For Aquinas, for instance, such practices had to be oriented to meet personal and family needs primarily and once they were met, the man had to give up working and earning more. Production of personal wealth by economic practices by extra work and trade was feared from a religious point of view for it would potentially lead to the bad habits of luxury, pleasure-seeking, indulgence, negligence and social degeneration in many cases (Ersoy, 2008: 100-101). And for Aquinas, the practice of charging interest on the debts was totally unacceptable. The right procedure that had to be followed in lending was the payment of the exact amount borrowed (Hagan, 2012: 21-26; Ersoy, 2008: 102-103).

Another practice that the people had to follow with caution was the setting of the prices in the market. For Magnus and Aquinas, the prices on the market had to reflect fairness. The prices had to be set with a consideration of the costs, labour and trader profit plus the purchasing power of the people. People had to be able to buy commodities at reasonable prices while the supply side was also to earn for their efforts. It followed from this thinking that the traders were not free to determine the price according to the free forces of the market with a view to the amount of supply and demand. What was strictly unacceptable was the attempt of the traders to sell the products over their real value to exploit the needs of the people. For Aquinas, trade conducted on these principles which also involved the allocation of charity for the poor was a highly virtuous practice (Hagan, 2012: 18-21).

Regarding their view to the ownership of the property, the scholastic scholars stressed that the man had the right to claim private ownership of the property for various needs and purposes as a viceroy of the God on earth. Property essentially belonged to the God as the creator and sole owner of everything. And it was the God who bestowed with His greatness the rights of property to the man. According to Aquinas (II-II, Q.66, A.1, A.2), there were great uses in the private ownership of property for the reasons that the individual owners would take better care of their properties and that 
they would be encouraged to produce more efficiently. As they would be able to claim the products produced from their property, they would be inclined to make the best maintenance and use of it. That would eventually contribute to the emergence of a vivid economic life too. But for Aquinas, there were space for public ownership of the property as well in economic life which had been present since the beginning of history (Ersoy, 2008: 100). Those things possessed by the state, those of others like forests, rivers, seas etc. were all used publicly for good reason. And Aquinas viewed it equally necessary to decrease the income gap between the rich and the poor by such means as taxation and charity as duties expected from the rich.

\section{Protestant Scholars}

The protestant scholars like Martin Luther and Jean Calvin strayed from the views supported by the scholastic scholars to remarkable extents. They endorsed the Aristotelian view that man was a social being and he had to live in cooperation with the others for a decent life (Tannenbaum, 1998: 113). Production and trade were essential for these reasons, and the man had the right to claim personal rights over the property for purposes similar to the views of the scholastic scholars (Ersoy, 2008: 108-109). But unlike the scholastic scholars, economic activities could not have been limited to the meeting of immediate needs only. Luxury and extravagance had to be avoided, but it was normal to work to make fortunes and accumulate wealth. And indeed it was encouraged to work and earn a lot to enjoy the blessings of the world bestowed by the God by also helping the society with various means (Hart, 1995: 132-135). And though foreign trade was to be avoided according to Luther with fears that it would encourage luxury and degeneration, it was permissible for Calvin for it could have provided relief in times of economic crisis and scarcity (Ersoy, 2008: 110).

Luther and Calvin were not with the idea that the interest had to be prohibited from economic life in its entirety. Interest was not a normal way of earning money and it was not liked generally, but it could have been permitted within certain limits. It was not right to charge interest on the debts of the poor borrowed for basic needs, but reasonable rates of interest could be tolerated for debts borrowed for investment (Eaton, 2013: 3, 5). The real problem was that actually interest was so widespread in Europe and that it was not possible to eradicate it. But also because capitals borrowed with interest could have led the borrowers to earn fortunes and they could have created jobs and other opportunities for the people (Ersoy, 2008: 107-109). Encouraging economic entrepreneurialism by such means, Luther regarded the agricultural life and proximity to the nature as very important, however; for religion had historically developed and flourished in such life.

The idea of fair price determined according to the costs, labour, trader share and the needs of the people was not endorsed by Luther and Calvin. They argued that the prices had to be left to the forces of the market and that the market had its own mechanisms to keep the prices at proper levels with the condition that the traders were not to engage with monopoly, black-marketing, and speculation (Eaton, 2013: 2-3). Such undesired practices like the latter were to be prevented by the state.

\section{Islamic Scholars}

The Muslim scholars of the Middle Ages who cogitated over the essential rules and principles that must be followed in the economic life share surprising similarities with the Christian scholars of their age though casting their uniqueness in the details. Gazali, Farabi, and Ibnu Khaldun agree with the Aristotelian view that man was created in needs; that he could not meet all his needs on himself; that he had to live in cooperation with the others; and that he had to cast his labour to produce items for his own use and to exchange for those of others that he could not produce. Production, specialization, and trade were therefore deemed as essential economic activities (Ersoy, 2008: 122-123, 126, 136-137).

But that does not mean the Muslim scholars supported a substantially liberal view to economy. There were some items whose production and trade was prohibited, for instance, which included alcoholic beverages, pork, carcass, blood, and the meat of animals which were not slaughtered in an Islamic way (Al-Quran, Sura 2, V. 173; Sura 5, V. 3). And it was a moral obligation for the believers not to make any sacrifices from integrity in trade by notifying defects of the items, using the right measures, and observing the market price never trying to exploit the urgency of the needs by the people (Al-Quran, Sura 83, V. 1-5). They had to stay away from interest for it was an oppressive and unfair way of earning money. Interest was supposed to be prohibited for whatever purposes a person borrowed whether to meet the immediate needs or to invest in business (Al-Quran, Sura 2, V. 175-179). Apart from these, the believers were not prohibited from working and earning as much as they could to accumulate wealth and fortunes. That was even useful for the society because it contributed to the enrichment of the commodity markets and employment opportunities by also aiding the poor and the needy with the charity and the taxes collected from the rich. Payment of charity was promoted by more than 50 
verses in the Quran.

The generality of the Islamic scholars agreed with the protestant scholars that the market price was the fair price and that there must not have been any political intervention to its formation. Political intervention was deemed justified only in cases of monopolization, black-marketing, speculation, the sale of forbidden items and practice of forbidden activities. A hadith is reported by the Messenger Muhammed in this regard where the believers call from the Messenger for the placement of limits on the prices of the goods in the market with the excuse that they got very expensive. But the Messenger rejects the request by saying that "It is the God who sets, reduces and increases the prices. I want to meet with the God (after the death) as a person who did not oppress anyone" (Ebu Davud, 51, 3450). The political regulation of the commodity prices was accordingly regarded as oppression.

The Muslim scholars spared an active role in the economy to the state considering the state as a highly useful and necessary public entity providing critical services to the people. The state was first and foremost expected to ensure justice in the country by applying the laws, preventing crime and guaranteeing the fulfilment of the contracts. As it was often remarked, justice was the base of the property. In a country ravaged by theft, banditry, and absence of enforcement, economic life could not have thrived. Equally important for economic development was the provision of critical infrastructural services like the roads, markets, water, inns, policing, security etc. by the state which could not have been sustained by the individuals except with high costs (Ersoy, 2008: 130-131, 137-140).

In addition to these, ibnu Khaldun, for instance regarded the state as a major consumer and producer of goods with its benefits spilling over the public and the private sector. The state was the mother of all the markets according to ibnu Khaldun whose activism was supposed to be preserved even at the cost of short term losses. The statesmen had to heed that the decline of state expenditures would eventually lead to the decline of the general level of wealth and prosperity in the country and thus the amount of taxes collected. Therefore, they had to be ready to spend even in times of recession (Ali, 2006: 10-11).

According to the Islamic scholars, the state was also expected to administer the collection and distribution of ratios of taxes levied on the wealth of the people. Such taxes included, for instance, the Zakat, tithe and humus whose rates were $1 / 40,1 / 10$ and $1 / 5$ in order charged according to the character of the revenue. These taxes were primarily to be used for the poor, the needy, the orphans, the immigrants etc. but also to meet various state expenditures in its effort to ensure justice, security and stability in the country (Islahi, 2006).

Similar to the Christian scholars, the Muslim scholars condemned luxury, extravagance and irresponsibility by the statesmen to consider them as major causes of economic and political disorder. For Ibnu Khaldun, for instance, as the statesmen sought for luxury and comfort, they would fail to carry out their critical duties cited above. The revenues would decline, the taxes would rise, the people would get poor and eventually reactive to and discontent with the statesmen. In the absence of political leaders who were willing to perform their duties for the people, the country would be open to the invasion of the other states or the rival elites in the country (Islahi, 2006).

\section{Mercantilism}

As a general economic policy line and practice nurtured by the monarchies and empires from the $15^{\text {th }}$ to the $18^{\text {th }}$ centuries, mercantilism was also influential on the formation of the principles of economic conservatism. The major goal in mercantilist practices was to ensure national development and ascendancy promoting national interests in the domestic and international environment. Even though mercantilism was a substantially nationalist and secular economic ideology and practice, it contributed significantly to economic conservatism because in the medieval and pre-modern era religious institution often went hand in hand with state. Loyalty to the state was a religious duty in Islam and Christianity as well as in other religions often with clear statements in religious doctrines or practical concerns. Even though the state had various non-religious attributes, it was more reasonable for the religion to work with the state and share its major concerns for it was the most powerful military, political and administrative body existing in religious environments which promised favours to the religion in case of its cooperation. State was always deemed as a useful public entity which provided more benefits than harm.

The general principles of mercantilism could be summarized as powerful central state, substantial state involvement in the economy, promotion of exports against imports in foreign trade, economic development and growth, collection of massive state revenues expressed in terms of gold and silver (Ekelund and Hèbert, 2014: 47-52). These principles were supported by conservative political formations from the $19^{\text {th }}$ century onwards for the simple reason that the state interests were regarded as conservative interests and the state was a very essential and integral element of conservative thought.

The central state was instrumental in ensuring national unity, solidarity and interest. The central state would 
provide the necessary legal, political and administrative services needed for the conduct of economic activities. It would ensure domestic peace and order, and would defend the national interests against rival states. In Europe, many countries suffered from barriers to trade even in their domestic environment and without a powerful central state which removed domestic customs and limitations, economies would never develop (Ersoy, 2008: 161-164).

The mercantilist thought viewed it necessary for the state to act as an active economic agent. The state was supposed to invest in various sectors of the economy which promised great returns when the bourgeoisie failed particularly. The state was also supposed to promote exports against the imports to minimize dependence on other countries but most importantly to maximize the amount of precious metals present in the country. The production and trade of commodities promising great returns was to be promoted. Export taxes were to be removed and imports had to be taxed heavily. Accordingly, the greater the amount of precious metals in a country, the more powerful would it be against the other states.

Development and growth was a major motivation in mercantilist thought. The borders had to be protected and expanded if possible. The empires had to rapidly take their shares in the colonies. Politics was a zero-sum game where the gains of a country meant the loss of the others. Political power relied heavily on economic power for the erection of armies, fleets, advanced weapons required huge expenditures.

\section{Post-Enlightenment and Post-Revolutionary Era}

With the domination of the global political landscape by modern states established on Westphalian principles, the conservatives assumed a particular posture towards their political and economic environment that displayed much uniformity across the modern world. Most of the conservative thinkers and formations ceded to the demands of the modern state to be the major arbiter of political and economic power, and turned to forge a proper place for themselves within the legitimate political sphere. State interests were respected either for essentialist or for instrumental reasons, and participated in most cases. Patriotism was one of their major characteristics that found its expression in the struggle to establish a powerful, independent and glorious state. Most of them maintained the mercantilist zero-sum view to international economics and politics as well regarding the advancement and glory of the other countries as a threat to theirs.

The conservatism in American history provides a good case in point to evince the theses above. It was one of the major goals of the American conservatives in the $18^{\text {th }}$ and $19^{\text {th }}$ centuries to unify the colonial states under a central state that would administer the political and economic resources of the country from a single hand in a well coordinated fashion. A central state would serve to national ascendency and glory much better than a confederal or federal state. The vast resources of the country were wasted in the absence of central planning to take care of the law, justice, investment, infrastructure, foreign debts and overdependence on British goods. The early representatives of conservatism in America, the Federalists led by Alexander Hamilton and John Adams, ${ }^{1}$ failed to achieve a central state, but they went on to further their goals by other means when they were in the government like with a national economic development scheme that included subsidized or state-led industrial development initiatives, construction of federal highways, water canals, river improvements, railroads, communication networks along with a policy of tariffs against imported goods (Allitt, 2009: 1415, 21).

An important policy that the federalists supported was the establishment of a national bank to serve towards the economic unity and well-being of the country. The country was suffering from foreign debts borrowed by various states, lack of a unified currency, lack of proper national economic coordination, and rampant usury. A national bank was established in 1791 with his efforts to help deal with these problems which functioned until 1811. While not being very successful in meeting its establishment goals, the bank was regarded as a valuable institution when its closure was followed by a serious currency instability crisis. The bank was therefore established for a second time in 1816 to prove even more successful this time by managing a national currency, holding revenues for the government, supporting the treasury, restraining the lending practices of the usurers, and most importantly supervising the payment of the national debts. The national currency managed by the bank helped ensure the economic unity of the country with its usage across the country (Sylla, 2004: 33-37).

The bank was a major source of backlash by the liberals, however. Accordingly, the bank decisions were taken behind closed doors by those who declared that they were not accountable to the elected officials. That was a threat to popular sovereignty for the liberals. So when the charter of the bank had expired in 1836, the law for its extension was

${ }^{1}$ The Federalist Party is the first political party established in the US in 1790 to survive until 1816. It held the federal government in the US until 1801. 
vetoed by US president Jackson despite the fact that it was approved by the house of representatives and the senate with sizable majorities. Jackson had vetoed it with the excuse that it undermined democratic prerogatives by creating an aristocratic class with state funds irresponsible to popular surveillance. The bank was closed down and all the federal funds were transferred to smaller banks in the states (Hammond, 1985: 444-446; Schlesinger, 1946: 87-98).

The American conservatives were allied with the liberals on the issue of private property against the Marxists. Property was so fundamental and natural to human beings as family and its existence even predated the state. The Marxist tendency to see the private property as theft was unacceptable for private ownership of the property was very essential for purposes of economic justice, self identification, social responsibility and leisure among many things. There could not be anything more reasonable than a person owning the products of his own labour and exertions. And it was not fair to distribute the property among those who contribute in different rations to its production. The right thing to do was to give everyone the share that he produced. And it was by declaring the products of his own efforts as belonging to him, by saving as he wishes, by spending as he desires, by taking care of the livelihood of his family that a man was able to identify himself. The abolition of the private property and public ownership would be inefficient and chaotic with the people relying on the labour of the others and trying to evade public responsibilities assigned to them. Private property had to be protected and promoted by the state, therefore (Lieber, 1842: 37-58).

But that was often the only common point that the American conservatives shared with the liberals for on many other issues the conservatives the liberals together with their culture and agents. The wealthy capitalists that had emerged with various types of entrepreneurialism were deemed as one of the leading causes of multiple social, cultural and economic problems the country was facing. Their only concern was to acquire wealth without any care for culture and civilization unlike the aristocrats who were a class of virtue, knowledge, responsibility and artistic concern. It was not possible to maintain a great civilization with them for it required piety, social responsibility and artistic concerns. The capitalists were greedy, irresponsible and haughty towards the people they hired and their lending practices were despicable. Many of them were usurers charging high interest rates on those who had to borrow for reasons. It was a serious problem for such a greedy and uncivilized class of men to reside over such amounts of wealth without any political control (Allitt, 2009: 106-114).

When he was the president of the US, Theodore Roosevelt went ahead with a federal government program that aimed to limit capitalist abuses towards the society and the workers that also included various social and economic programs. Roosevelt agreed with the pessimistic view of his contemporary conservatives towards the capitalists: The capitalists were greedy fortune-seekers and they despised the people who worked for them exploiting them to the maximum capacity possible. His government therefore took initiatives to curb capitalist monopolies by various means including adoption of laws favourable to workers, lawsuits, taxation, cross-border surveillance, and introducing parallel state enterprises to compete with them (Roosevelt, 25 March 1908; Roosevelt, 3 December 1901). The major political instrument that he used against the capitalists was democracy which he saw as an indispensible weapon that gave voice to the poor masses regarding their well-being and prosperity. He believed that the generality of the people, who were also poor, were aware of the capitalist abuses and would be willing to support his campaign against them.

The conservatives were particularly worried about capitalist political activism and impending threat of plutocracy (rule by the vulgar rich). The capitalists were not just confined into the economic sphere but were also motivated to secure positions in political institutions and negotiate clients among the politicians. They were aware that they would promote their interests best if they were able to exert power and control over the upper political chambers as representatives, by clients or by various means of persuasion inhibiting anti-capitalist decisions and introducing favourable ones (Allitt, 2009: 106-114).

The conservative distaste with economic liberalism was maintained by the southern agrarians in the US particularly because it threatened the traditional agrarian society and culture with its motivations to more closely integrate the agricultural life with manufacturing and industrial sectors. In pursuit of industrialization and material wealth, America was distancing from the beauty of the nature, dignity of labour, social integrity and artistic achievements. Industrial societies were unnatural, unstable and corrosive of tradition and virtue especially. America had to preserve its traditional agricultural formation which was the main source of its humanism, civilization and authentic identity. The southern agrarians thus opposed the mechanization and industrialization of the agricultural life and were fiercely opposed to the transfer of the agricultural fields to what they called as the enemies of the farm life which included the bankers, machinery marketers and mortgage brokers. They believed that there was a clear link between the type of economic activities and the socio-cultural norms and values which was very susceptible to constant change and progress (Twelve Southerners, 2006: xi-91).

In the beginning of the $20^{\text {th }}$ century, Hilaire Belloc introduced some new features to conservative economic thought somewhat straying from the conventional posture. According to Belloc, in the dominant economic paradigm of capitalism, 
property and means of production were possessed by a small minority of capitalists who exploited the labour and the resources of the majority as veritable slaves. The rights and freedoms brought by liberalism didn't mean much for the mass of the people for it was not possible to use them properly due to economic limitations. They served best to the interests of the capitalists who also tried to manipulate democracy into plutocracy to secure their establishment in political terms. The solution that Belloc offered for the problem was the mass distribution of the property or public ownership and administration by the civil servants (Belloc, 1912: 59-60, 64, 70-72). In distributing the property, it would be more proper to consider each family as a unit rather than the individuals, a scheme that could be better expressed as "family ownership of the property." By this way, the families would be protected from the grip of the greedy industrialists; and that they would arrange their economic activities according to their own choices; and thus would live more safely and longer (Belloc, 1912: 102-103).

The early $20^{\text {th }}$ century conservative Gilbert K. Chesterton (2008: 89-94) shared with his temporaries the view that capitalism was the enemy of artistic and aesthetic production, and that it deceived the people by various psychological tricks and impositions, and that it was particularly destructive of small scale manufacturers. This was expressed as follows in the Outline of Sanity (2008: 68)

"The work is much more likely to be neat if it is done by a particular craftsman for a particular customer with particular ribbons and flowers. The person told to trim the hat will never do it quite suitably to the person who wants it trimmed; and the hundredth person told to do it will do it badly; as he does. If we collect all the stories from all the housewives and householders about the big shops sending the wrong goods, smashing the right goods, forgetting to send any sort of goods, we should behold a welter of inefficiency."

With advertisements, promotions and such inducements, people were captured into a capitalist web of vicious circle. In political terms, the state was stealthily captured by the capitalists, usurers, and bankers and the people were victimized by various political illnesses emanating from plutocracy. Against all these, Chesterton $(2008: 79$, 99) was suggesting the abandonment of the use of big markets, the inhibition of the growth of capitalism and the protection of small scale manufacturing and property by the state. A viable alternative was return to simple farm life to help people recover from the complexity and the troubles of the urban life to live more meaningfully, consciously and naturally in their simple pastoral setting (Chesterton, 2008: 101-103).

Conservative economic thought found ample space of application during Federalist, Whig and Republican Party governments in US history. The republican president Theodore Roosevelt, for instance, put many of them into action in his economic rescue program named as New Deal. With the New Deal, the federal state initiated various social aid campaigns, labour programs, and public enterprises for purposes of irrigation, electricity production and transportation. The New Deal increased public controls over the capitalists and provided government support to the farmers (Himmelberg, 2000: 12-20).

For all these, economic conservatism in the $19^{\text {th }}$ century had a perplexing libertarian streak as well that differed from traditional approaches in full contrast. Represented by such names as William Graham Sumner (1840-1910) and Andrew Carnegie, libertarian conservatism endorsed free market capitalism, limitation of state economic activism, removal of barriers against domestic production and international trade and limitation of public welfare expenditures. They were dismissive of religion, tradition and hierarchy in economic life like the liberals yet observing great utility in economic inequality. Inequality was the engine of progress for them by which the poorer would be motivated to work under wealthier to meet his livelihood. The libertarian conservatives had concern for culture and civilization but they held the view that America would have a glorious civilization only when entrepreneurial capitalism was given full freedom. They were the defenders of charity, however. For Carnegie, a millionaire was supposed to distribute his wealth during his life time and he had to donate for libraries, colleges, churches, orphanages, research institutes and for such purposes (Allitt, 2009: 100-103).

\section{Conclusion}

This article is devoted to the exploration of the major principles and characteristics of economic conservatism with a historical, theoretical and empirical dept. It starts with the examination of the views of scholastic, protestant and Islamic scholars to major economic issues; and it goes on with the elements that economic conservatism shares with mercantilism; and it finalizes with a detailed analysis of the economic conservatism in the example of late $18^{\text {th }}$ to early $20^{\text {th }}$ century US economic history. The religious scholars share interesting commonalities despite the difference in faith. They all argue against luxury and pleasure-seeking, black marketing, monopolization, interest; and they all agree on their 
support for private property, reduction of the income gap, taxation of various private economic activities, and extensive state involvement in the organization and regulation of the economy. Small differences exist, however, for while the scholastic and Islamic scholars prohibit interest in its entirety, protestants permit it if for investment. Again, the protestant and Islamic scholars argue that market price is the fair price, but the scholastic scholars argue that the prices must not be left to the free forces of the market. Economic conservatism borrows from mercantilism the idea of economically powerful and active state, favourable trade balance achieved through the promotion of exports and obstruction of imports, zerosum view to international economics, and achievement of national economic development and glory. In the example of the history of US economic life until the early $20^{\text {th }}$ century, economic conservatism adopts almost all the views and characteristics of religious scholars and mercantilism like the avoidance of luxury and pleasure-seeking, interest, monopolization etc.; and support for economically united, powerful and active state, taxation, private property, favourable trade balance, and zero-sum view to international economics. But it acquires some new tenets as well like the campaign for running a central bank and national currency, broad welfare and social policy expenditures, strong opposition to capitalism, bourgeoisie and plutocracy, promotion of pastoral farm life, reduction of the income gap via the distribution of the property held by the capitalists, this all notwithstanding the libertarian streak that stands in radical contrast to all the above.

\section{Acknowledgements}

This paper is presented as part of a project funded by the Research Management Centre of University Technology Malaysia, UTM, with the project code 01K69. Special thanks to the UTM and Malaysian Ministry of Education for the generous support provided.

\section{References}

Al-Quran.

Ali, Salman Syed. 2006. "Economic thought of Ibnu Khaldun," IRTI: Islamic Development Bank. pp. 1-15.

Aquinas, Thomas. 1981. Summa Theologiae (The Substance of Theology). Trans. English Dominican Fathers. New York: Christian Classics.

Allitt, Patrick. 2009. Conservatives: Ideas and Personalities Throughout American History. New Haven, CT: Yale University Press.

Belloc, Hilaire. 1912. The Servile State. London and Edinburg: T.N. Foulis. -.. 2008. Economics for Helen: A Brief History of Real Economy. Norfolk, VA: I.H.S. Press.

Chesterton, Gilbert K. 2008. Outline of Sanity. Norfolk, VA: I.H.S. Press.

Eaton, David H. 2013. "The Economics of Reformation: An Overview of Reformation Thinking Concerning Work, Wealth and Interest," Sage Open 3(3): 1-9.

Ekelund, Robert B. and Robert F. Hébert. 2014. A History of Economic Thought and Method. $6^{\text {th }}$ edition. Illinois: Waveland.

Ersoy, Arif. 2008. Iktisadi Teori ve Dusunceler Tarihi (History of Economic Theory and Thought). Ankara: Nobel.

Hagan, Michael J. 2012. "Thomas Aquinas: Economics of Just Society," Austrian Student Scholars Conference. Wien, Austria.

Hammond, Bray. 1957. Banks and Politics in America from the Revolution to the Civil War. Princeton: Princeton University Press.

Hart, lan. 1995. "The Teaching of Luther and Calvin about Ordinary Work: 2. John Calvin," Evangelical Quarterly 67(2): 121-135.

Islahi, Abdul Azim. 2006. "Ibnu Khaldun's Theory of Taxation and Its Relevance Today," International Meeting on Tradition and Modernity in the Arab-Muslim Economic Thought: The Contributions of ibnu Khaldun. Madrid, Spain.

Lieber, Francis. 1842. Essays on Property and Labour. New York: Harper \& Brothers.

Roosevelt, Theodore. 3 December 1901. "First Annual Message," extracted from http://millercenter.org/president/roosevelt/speeches/ speech-3773

---------. 25 March 1908. "Message Regarding Labour Legislation," extracted from http://millercenter.org/president/roosevelt/speeches/ message-regarding-labor-legislation

Schlesinger, Arthur Meier. 1946. The Age of Jackson. Boston: Little Brown \& Company.

Sylla, Richard. 2004. "Hamilton and the Federalist Financial Revolution, 1789-1795," The New York Journal of American History 65(2): 32-39.

Tannenbaum, Donald. 1998. Inventors of Ideas: Introduction to Western Political Philosophy. New York: Wadsworth.

Twelve Southerners. 2006. I will Take My Stand: The South and the Agrarian Tradition. Louisiana: Louisiana University Press. 